\title{
Trade, Wage Gaps, AND SPECIFIC Human CAPITAL ACCUMULATION
}

\author{
NGO VAN LONG \\ RAYMOND RIEZMAN \\ ANTOINE SOUBEYRAN
}

CESIFO WORKING PAPER NO. 911

CATEgORy 7: TRAde Policy

APRIL 2003

\footnotetext{
An electronic version of the paper may be downloaded

- from the SSRN website:

www.SSRN.com

- from the CESifo website:

www.CESifo.de
} 


\title{
Trade, WAGE GAPS, AND SPECIFIC HuMAN CAPITAL ACCUMULATION
}

\begin{abstract}
We develop a new framework for the analysis of the impact of trade liberalization on the wage structure. Our model focuses on the decision of workers to accumulate firm-specific skills, by "on-the-job" training, knowing that this means their future wages will have to be negotiated, and that the outcome of negotiation will depend on the profitability prospect of firms operating in a new trading environment. We show that trade liberalization may reduce the welfare of a developing country because of its adverse effect on skill accumulation. We also explore the effects of trade liberalization on the wage gap between skilled and unskilled workers.
\end{abstract}

JEL Code: F10, F16.

Keywords: wage gap, human capital, trade liberalization.

\author{
Ngo Van Long \\ Department of Economics \\ McGill University \\ 855 Sherbrooke St West \\ Montreal, Quebec H3A 2 T7 \\ Canada \\ ngo.long@mcgill.ca
}

\author{
Raymond Riezman \\ Department of Economics \\ University of Iowa \\ $W 210 \mathrm{PBB}$ \\ Iowa City IA 52242-1000 \\ USA \\ raymond-riezman@uiowa.edu
}

\author{
Antoine Soubeyran \\ GREQAM, \\ Universite de la Mediterranee \\ Chateau La Farge, Route des Milles \\ 13290 LES MILLES \\ France \\ soubey@univ-aix.fr
}

We would like to thank seminar participants at Southern Methodist University, Penn State University, Florida International University, the Midwest International Economics Group and particularly Elias Dinopoulos for helpful comments and suggestions. 


\section{Introduction}

The exects of trade liberalization on wage structure, employment, income distribution, and welfare, have been a continuing topic of debate. (See, for example, Wood (1994), Freeman (1995), K rugman (1995, 2000), Leamer (1998, 2000), Davis (1998), Falvey (1999), Tyers and Y ang (1999), and the Review of International Economics special issue on globalization and labor markets, A ugust 2000.) E conomists participating in this debate typically use a modi..ed version ${ }^{1}$ of the Heckscher-Ohlin model, with ...xed endowments of skilled and unskilled workers. T wo prominent exceptions to this ..xed endowment formulation are the papers by F indlay and K ierzkowski (1983) and Deardorø $(2000)^{2}$. In both papers, workers choose either to remain unskilled, or to become skilled by undertaking investment in general human capital. Their models, however, do not deal with an important fact of the labor market: a large amount of human capital is ..rm-speci..c. In the labor economics literature, ..rm-speci..c human capital has been considered by many authors as a factor contributing to the stylized fact that in many industries, the wage pro..le is steeper than the marginal productivity pro..le. (For a review of the empirical literature on ..rm-speci...c human capital, see Hutchens, 1989; a companion paper by Carmichael, 1989, reviews the underlying theoretical models, including the path-breaking work of Becker, 1962.) Firm-speci..c human capital introduces a non-competitive element in wage determination. It would seem that a model of trade that takes into account this feat ure could produce results that are signi..cantly dixerent from those obtained under the hypothesis of perfectly competitive labor markets. In particular, in such a model, the exects of trade liberalization on human capital formation, wage structure, and welfare could signi...cantly depart from the standard results.

This paper presents a simple model of ..rm-speci..c human capital accumulation in an open economy that contemplates trade liberalization. Our model focuses on the decision of workers to accumulate ..rm-speci..c skills ${ }^{3}$,

\footnotetext{
${ }^{1}$ For models with non-competitive product markets, see D inopoulos and Segerstrom (1999) and Neary (2000).

${ }^{2}$ We should also mention a dixerent stream of literature that studies instead long-run issue associated with human capit al accumulation. See Lucas (1988), Y oung (1991), Stokey (1991), and, for a survey of the trade and growth literature, see L ong and W ong (1997). These authors however focused on long run considerations, and did not consider short-run issues such as the accumulation of industry-speci..c and ..rm-speci..c human capital, in response to trade liberalization.

${ }^{3}$ Recall that our approach is dixerent from that of F indlay and K iezkowski (1983) and
} 
knowing that this means their future wages will have to be negotiated, and that the outcome of negotiation will depend on the pro..tability of ..rms operating in a new trading environment. We obtain a set of interesting results. A surprising result is that a developing country may be harmed by trade liberalization. This is in sharp contrast to the standard gains-fromtrade proposition obtained for models built on the assumption of perfectly competitive markets for goods and factors of production. The main reason for our loss-from-trade result is that in our model, the labor market is not perfectly competitive: the wage of workers who possess ..rm-speci..c skills are not taken as given by ..rms. When skills are ..rm-speci..c, each ..rm has an incentive to negotiate the wage rate after such skills have been accumulated. Thus, under autarky, the market outcome is not Pareto ed cient. It is known that, under technological externalities, or common property externalities, a move from autarky to free trade may be harmful (see, for example, B rander and Taylor, 1998, Chichilnisky, 1994). In our model, there are no externalities, but the lack of a perfectly competitive labor market can cause distortions that resemble externalities.

We show that, for a developing economy (one which imports the hightech good), the expectation of trade liberalization leads to less human capital accumulation by workers in the high-tech industry. In the absence of perfectly competitive labor markets (in our model wages are negotiated between management and workers with ..rm-speci..c skills), the exect of trade liberalization on the supply of skills may be welfare-worsening. This concern, which our model will formalize, has been forcefully expressed in some circle, as the following quotation from Hirschman (1969, p. 5) illustrates:

"The opponents of free trade have often pointed out that for a variety of reasons it is imprudent and harmful for a country to become specialized along certain product lines in accordance with the dictates of comparative advantage. Whatever the merits of these critical arguments, they would certainly acquire overwhelming weight if the question arose whether a country should allow itself to become specialized not just along certain commodity lines, but along factor-of-production lines. Very few country would ever consciously wish to specialize in unskilled labor, while foreigners with a comparative advantage in entrepreneurship, management, skilled labor and capital took over these functions, replacing inferior "local talents."

Our model can shed light on the exect of trade liberalization on wage

Deardorø (2000): these authors assume that human capital is not ..rm-speci..c. 
gaps. An implication of our model is that the wage gap between high and low skill workers increases in the country that exports the high-tech good and decreases in the country which imports the high-tech good. While this result is also predicted by the Heckscher-Ohlin model, we get additional results that are of interest in understanding wage gaps. For example, in Proposition 6, we describe the exects of technology shocks and trade shocks on the wage gap. The combination of technology shocks and trade shocks may explain the stylized fact that wage gaps have been increasing in all countries. In section 4 we brieły discuss the policy implications of our results as well as the exects of externalities and uncertainty.

Before proceeding, it may be useful to compare in some details our approach to human capital formation with those of Findlay and Kierzkowski (1983) and Deardora (2000.) Apart from the main dixerence (..rm-speci..c human capital in our model, versus general human capital in their models), we should mention several dixerences and similarities. In Findlay and Kierzkowski ( $F-K)$, workers are ex ante homogenous, but ex post, some of them become skilled workers, and others remained unskilled. The life-time income, net of education costs, is the same for both types of workers. Our model shares this characteristic. Education in $\mathrm{F}-\mathrm{K}$ is model led by postulating a neoclassical function using two inputs (a ..xed stock of capital, $K$, and students, E ) to produce skilled workers Q; under constant returns to scale. We assume, by contrast, that unskilled workers acquire ..rm-speci..c skills by working within a ..rm (which possesses a unit of capital) and incurring resource costs, a strictly convex function. $\mathrm{F}-\mathrm{K}$ assume that the production functions for the two consumption goods have two substitutable inputs: skilled labor and unskilled labour. They explain the pattern of trade in terms of relative factor endowment: a country with a high ratio of capital to population $\mathrm{K}=\mathrm{N}$ will export the skilled intensive consumption good. In our model, comparative advantage can be explained in terms of dixerences in endowments, or technology, or cost of education. Unlike F-K, Deardora (2000) assumes that workers are ex ante heterogenous: they dixer in terms of ability to learn. $O$ ur present model can be extended in this direction, without changes in the essential results ${ }^{4}$. The focus of Deardora's paper is policies for redistributing income, while we focus on the exects of trade liberalization on wel fare and wage gaps.

\footnotetext{
${ }^{4}$ In fact, an early version of this paper includes this case.
} 


\section{A B asic M odel of Human Capital A ccumulation}

\subsection{Assumptions and Notation}

We assume that there are two periods. A s a ..rst step, let us consider a small open economy, consisting of two sectors, denoted by $G$, and $H$. ( $G$ and $H$ stand for general and speci..c human capital respectively.) One can think of sector $\mathrm{G}$, which produces output $\mathrm{Q}_{\mathrm{G}}$, as the "low-tech" sector consisting of goods such as textiles and clothing. The "high-tech" sector's output, $\mathrm{Q}_{H}$; represents goods such as pharmaceuticals, software, computers, etc. Each individual in this economy possesses one unit of general human capital, and can accumulate ..rm-speci..c human capital. Let good $\mathrm{G}$ be the numeraire good. The price of this good is $P_{G}=1$. The only factor of production used to produce good $\mathrm{G}$ is general human capital. Production in sector $\mathrm{G}$ is under constant returns to scale: one unit of general human capital produces $W_{G}$ units of good $\mathrm{G}$. Thus the wage rate in this sector is $W_{\mathrm{G}}$ in both periods.

Good $\mathrm{H}$ is produced using industry-speci..c physical capital, and workers, who have either general or ..rm-speci...c human capital. A ssume that thereare $\mathrm{N}_{\mathrm{H}}$..rms in sector $\mathrm{H}$ and that each ..rm is endowed with one unit of industryspeci..c physical capital. $\mathrm{N}_{\mathrm{H}}$ is exogenously given: For the time being, the price of good $\mathrm{H}$ in period $\mathrm{t}$, denoted by $\mathrm{P}_{\mathrm{t}}$, is taken as a parameter. In a subsequent section, we shall consider autarky equilibrium and show how $\mathrm{P}_{\mathrm{t}}$ is determined endogenously.

We assume that, in sector $\mathrm{H}$, to produce a positive output, a ..rm must have one unit of industry-speci..c physical capital, and exactly one worker: a second worker would add nothing to output. If the worker (who works with one unit of industry-speci..c physical capital) has only one unit of general human capital, then the output is 1 unit of good $\mathrm{H}$. If he has accumulated, in addition, $h$ units of ..rm-speci...c human capital, then the output is $1+{ }^{1} h$, where ${ }^{1}$ is a positive parameter representing the productivity of ..rm-speci... human capital in sector $\mathrm{H}$. (Here, $\mathrm{h}$ is the worker's decision variable.) Since

1 is only relevant in period 2, one may also interpret it as a measure of technical progress embodied in ..rm-speci..c human capital, and ${ }^{1} \mathrm{~h}$ is ..rmspeci..c human capital measured in eф ciency units.

Initially,workers in sector $\mathrm{H}$ have no ..rm-speci..c human capital. In period 1, each sector $\mathrm{H}$ worker decides on $\mathrm{h}$, the amount of ..rm-speci..c human capital he wants to acquire. We assume that, without the ..rm's unit of speci..c physical capital, the worker cannot acquire ..rm-speci..c knowledge. The 
cost of acquiring ..rm-speci..c human capital depends on the amount $h$. We assume that to obtain $\mathrm{h}$, a worker must directly incur an exort cost which is denoted by $\mathbb{B C}(\mathrm{h})$, where $\mathbb{B C}(\mathrm{h})$ is convex and increasing, with $\mathrm{C}(0)=0$ : (Here ${ }^{\circledR}>0$ is a shift parameter, which we introduce to ref ect the fact that dixerent countries may have dixerent costs of education.)

We assume for simplicity that for the worker, the cost ${ }^{B C}(\mathrm{~h})$ can be measured in terms of good $\mathrm{G} .{ }^{5}$ Let $\mathrm{N}$ be the number of individuals in this economy. We assume that $\mathrm{N}>\mathrm{N}_{\mathrm{H}}$, so that when each ..rm in sector $\mathrm{H}$ employs one worker, there are enough workers left to produce the numeraire good.

At the beginning of period 2, a ..rm in sector $\mathrm{H}$ that has hired a worker in period 1 can rehire this worker, who has acquired $h, 0$ units of ..rmspeci..c human capital, at a wage $W_{2}$ (which is an outcome of a bargaining process between the .rm and the worker, to be discussed below), or it can dismiss that worker, and employ a new worker, who, of course, does not have ..rm-speci..c human capital: If it takes the latter course of action, its pro..t is $1 / R=P_{2} i W_{G}$. This is the ..rm's reservation level of pro.tt in its second-period bargaining with its worker. The experienced worker, on the other hand, can work in sector $G$ in period two, at the wage $W_{G}$. This is his reservation wage in his bargaining with his existing employer:

\subsection{A nalysis of Wage P ro..les}

We now turn to the question of how bargaining determines the wage of the skilled worker in period 2, given that the worker has acquired $\mathrm{h}$ units of ..rmspeci..c human capital. To do this, we use the theory of Nash cooperative bargaining, according to which the bargaining outcome in period 2 is a pair $\left(W_{2} ; 1 / \Psi\right)$ that maximizes the Nash product, $\left(1 / \Psi ; i^{1 / 4}\right)^{-}\left(W_{2} i W_{G}\right)^{1 i^{-}}$subject to the constraint that

$$
1 / 42+W_{2}=\left(1+{ }^{1} h\right) P_{2}
$$

\footnotetext{
${ }^{5}$ A lt ernatively, we can interpret $\mathbb{B C}(\mathrm{h})$ as the cost of education, which uses up real resources, identi..ed as good $\mathrm{G}$.
} 
where $\mathrm{h}$ has been determined in period 1 , and is taken as given ${ }^{6}$ in the bargaining problem. The parameter ${ }^{-}$represents the relative bargaining power of the ..rm, where $0-1$. The constraint (1) may be written as

$$
1 / 4+W_{2}=1 / 4+W_{G}+S
$$

where $\mathrm{S}={ }^{1} \mathrm{hP}_{2}$ is the surplus to be shared by the ..rm and the worker.

Solving this maximization problem yields the Nash-bargaining solution

$$
W_{2}=W_{G}+\left(1 i^{-}\right) S
$$

and

$$
1 / 4=1 / 4+-S
$$

Equation (2) says that the skilled worker's wage consists of two components: a wage that he would earn el sewhere, plus a share of the surplus that his skills (toget her with the..rm's capital stock) generate. Equation (3) indicates that ..rm's pro..t equals the sum of the pro..t it would earn if it were to employ a worker without ..rm-speci..c skills, and its share of the surplus generated by the skilled worker.

We now show how $\mathrm{h}$ is determined in period one. A ssume that there is no uncertainty, and that individuals can borrow and lend at a constant ${ }^{7}$ rate of interest $r$. Then in period 1 , a worker in sector $\mathrm{H}$ chooses to maximize his lifetime wage income, net of exort cost,

$$
W_{1} i \quad B C(h)+\frac{1}{(1+r)}\left(W_{G}+\left(1 i^{-}\right)^{1} h P_{2}\right)
$$

where he takes the ..rst period wage, $\mathrm{W}_{1}$; as given. Solving this maximization problem yields the ...rst order condition

$$
\left.\frac{\left(1 i^{-}\right)^{1} P_{2}}{(1+r)} ; \quad{ }^{\circ} 9 h\right)=0
$$

${ }^{6} \mathrm{An}$ alternative formulation, which would lead to a dixerent result, is that the bargaining would take place in period 1 , where the outcome would result in a contract that speci..es how much human capital the worker must acquire, as well as wage rates $\mathrm{W}_{1}$ and $\mathrm{W}_{2}$.

${ }^{7}$ The question of how $r$ is determined should also be addressed. This can be done most simply by assuming that individuals maximize life-time utility $U_{1}+\Psi_{2}$ where $U_{t}$ is quasi-linear $\mathrm{U}_{\mathrm{t}}=\mathrm{u}\left(\mathrm{X}_{\mathrm{Ht}}\right)+\mathrm{X}_{\mathrm{Gt}}$, with $\mathrm{u}^{0}>0, \mathrm{u}^{0}<0$, and \pm is a constant, $0< \pm<1$. $\left(\mathrm{X}_{\text {it }}\right.$ represents the amount of good $\mathrm{i}$ consumed in period t.) $\mathrm{T}$ hen, at an interior equilibrium, $1=(1+r)= \pm$ 
Condition (4) says that a worker acquires ..rm-speci..c human capital to the point where the discounted marginal gain in wage income in period two is equal to the marginal exort cost that the worker has to pay in period 1 to acquire the skills. From this equation, the optimal choice of $h$, denoted by $k$ is a function of $P_{2}$ and other parameters. We write

$$
A=A\left(P_{2} ;^{1} ;-; \circledR\right)
$$

It is easy to see that

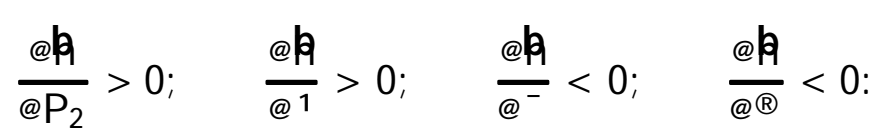

(Expectation of higher second period price, or of increased eф ciency encourage workers to accumulate more human capital. On the other hand, a greater bargaining power on the part of the..rm and higher learning cost lead to less investment in human capital.)

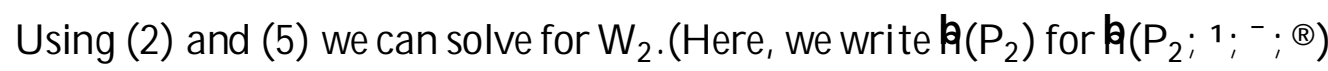
to save space.)

$$
W_{2}=W_{G}+\left(1 i^{-}\right)^{1} P_{2}{ }^{A}\left(P_{2}\right)^{\prime} W_{2}\left(P_{2}\right)
$$

Thus $W_{2}$ is increasing in $P_{2}$.

Next we determine the wage $\mathrm{W}_{1}$ of a sector- $\mathrm{H}$ worker in period 1 . We assume that prior to making the job choice decision in period 1 ; all workers are identical. This means that in equilibrium the expected life-time income (net of exort cost) of a sector- $\mathrm{H}$ worker must be equal to the alternative life-time income that he could obtain in sector $\mathrm{G}$ :

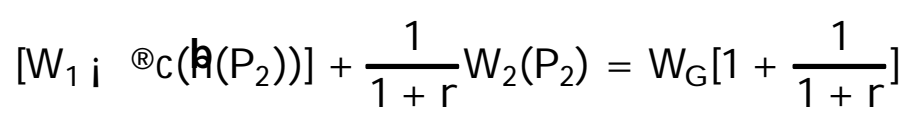

Thus

$$
W_{1}\left(P_{2}\right)=W_{G}+B C\left(A\left(P_{2}\right)\right) i \frac{1}{1+r}{ }^{h}\left(1 i^{-}\right)^{1} P_{2} R\left(P_{2}\right)^{i}
$$

Equation (9) says that in period 1, the employer pays the worker his outside wage, plus the cost of ..rm-speci..c education, minus the discounted value of the surplus ${ }^{8}$ that the employee can expect to capture in period 2.

${ }^{8} \mathrm{~T}$ his equation rełects the theory of on-the-job training, developed by Gary Becker (1962). 


\subsection{Autarkic Equilibrium}

To solve for an autarkic equilibrium, we must specify the demand side. The question of how $r$ is determined must also be addressed. This can be done most simply by assuming that individuals maximize life-time utility $U_{1}+ \pm_{2}$ where $U_{t}$ is quasi-linear, i.e., $U_{t}=u\left(X_{H t}\right)+X_{G t}$, and $u(:)$ is st rictly concave and increasing. The constant \pm is the utility discount factor, $0< \pm<1$. Then, in equilibrium, $1 \neq 1+r$ ) $= \pm$ (We assume that positive amounts of each good are consumed in each period.)

There are two alternative speci..cations of demand, but they lead to basically the same results. E ither one assumes that ..rms are owned by capitalists who are distinct from workers: they receive pro..ts, not wages, and they have the same utility function as workers. A lternatively, one can assume that each ..rm is equally owned by all $\mathrm{N}$ workers, and the pro..ts are distributed to workers, who are shareholders. In this formulation, we can talk about the representative individual. In what follows, we adopt the second formulation so that our welfare conclusions do not rely on adding up utilities of dixerent individuals.

Each worker-consumer-shareholder $\mathrm{i}$ chooses the vector of consumption $\left(\mathrm{X}_{\mathrm{G} 1}^{i} ; \mathrm{X}_{\mathrm{H} 1}^{i} ; \mathrm{X}_{\mathrm{G} 2}^{i} ; \mathrm{X}_{\mathrm{H} 2}^{i}\right)$ to solve the following maximization problem

$$
\max X_{G 1}^{i}+u\left(X_{H 1}^{i}\right)+ \pm X_{G 2}^{i}+ \pm\left(X_{H 2}^{i}\right)
$$

subject to the budget constraint

$$
X_{G 1}^{i}+P_{1} X_{H 1}^{i}+\frac{1}{1+r}\left(X_{G 2}^{i}+P_{2} X_{H 2}^{i}\right)=M+\frac{\mu_{N}}{N} \text { ? }
$$

where $M=W_{G}\left(1+\frac{1}{1+r}\right)$ is his life-time wage income ( net of learning exort $\operatorname{cost})$, and $\left(\mathrm{N}_{\mathrm{H}}=\mathrm{N}\right)$ ! is his dividend income, with

$$
1=1 / 41+ \pm 1 / 4
$$

where

$$
1 / 42=\left(1+{ }^{1 /} A\left(P_{2}\right)\right) P_{2} ; \quad W_{2}\left(P_{2}\right)=P_{2} i \quad W_{G}+{ }^{-1} h\left(P_{2}\right) P_{2}
$$

and

$$
1 / 4=P_{1} ; W_{1}\left(P_{2}\right)=P_{1} ; W_{G} ; \quad B C\left(R\left(P_{2}\right)\right)+ \pm\left(1 ;{ }^{-}\right)^{1} R\left(P_{2}\right) P_{2}
$$


Simplifying, we get

$$
i=P_{1}+ \pm P_{2}^{h} 1+{ }^{-1} h\left(P_{2}\right)^{i} ; M ; \operatorname{BC}\left(A\left(P_{2}\right)\right)
$$

We consider interior solutions (i.e., $X_{H t}^{i}>0$ and $X_{G t}^{i}>0$ for $t=1 ; 2$ )

Solving the maximization problem (10) yields the inverse demand functions for the high-tech good for period $\mathrm{t}$ :

$$
\left.\mathrm{u} 9 \mathrm{X}_{\mathrm{Ht}}^{\mathrm{i}}\right)=\mathrm{P}_{\mathrm{t}}
$$

from which we obtain the demand functions

$$
X_{H t}^{i}=D\left(P_{t}\right)
$$

where $D^{0}<0$. Thus all individuals have the same demand for good $H$ in period $t$. The sum of their demands are

$$
N D\left(P_{t}\right)
$$

Since there are $\mathrm{N}_{H}$ high-tech ..rms, the supply of the high-tech goods are given by

$$
\begin{gathered}
Q_{H 1}=N_{H} \\
Q_{H 2}=N_{H}\left(1+{ }^{1} h\left(P_{2}\right)\right)
\end{gathered}
$$

Equating demand to supply for the high-tech good, we get, for period 1,

$$
N D\left(P_{1}\right)=N_{H}
$$

and, for period 2,

$$
N D\left(P_{2}\right)=N_{H}\left(1+1 /\left(P_{2}\right)\right)
$$

These two equations determine the equilibrium autarkic prices $P_{1}$ and $P_{2}$, which we denote by $P_{1 A}$ and $P_{2 A}$. Next we substitute $P_{2 A}$ into (9) to obtain the period one autarkic wage 


$$
W_{1 A}\left(P_{2 A}\right)=W_{G}+B C\left(A\left(P_{2 A}\right)\right) i \frac{1}{1+r}^{h}\left(1 i^{-}\right)^{1} P_{2 A} A\left(P_{2 A}\right)^{i}
$$

while, for period 2,

$$
W_{2 A}=W_{G}+{ }^{1}(1 ;-)^{1} P_{2 A} A\left(P_{2 A}\right)
$$

Weare interested in ..nding out how our endogenous variables $\left(\mathrm{W}_{1 \mathrm{~A}} ; \mathrm{W}_{2 \mathrm{~A}} ; \mathrm{P}_{1 \mathrm{~A}} ; \mathrm{P}_{2 \mathrm{~A}}\right)$ vary across countries. To so that, we determine how these variables change with changes in our parameters $\left({ }^{1} ;{ }^{-} ;{ }^{\circledR}, \mathrm{n}_{\mathrm{H}}\right)$ where $\mathrm{n}_{\mathrm{H}}=\mathrm{N}_{\mathrm{H}}=\mathrm{N}$.

\subsection{Autarky Results}

From (17), we get the autarkic equilibrium price $P_{2 A}$ of a country as a function of the parameters ${ }^{1},{ }^{-} ;{ }^{\circledR}$ and $\mathrm{n}_{\mathrm{H}}$ (de. ned as $\mathrm{N}_{\mathrm{H}}=\mathrm{N}$ ). Dixerentiating (17) totally, we obtain

$$
\begin{aligned}
& D^{9}\left(P_{2 A}\right) d P_{2 A}=1+{ }^{1} A\left(P_{2 A} ;^{1} ;^{-} ;{ }^{i}\right) d n_{H}+n_{H} A\left(P_{2 A} ;^{1} ;^{-} ; \circledR\right) d^{1}+
\end{aligned}
$$

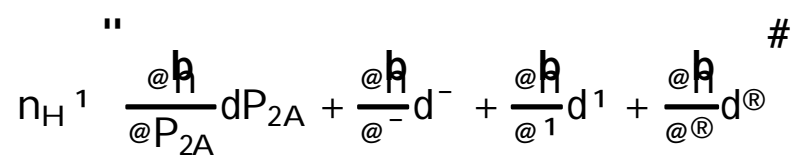

Let

$$
J=D^{9}\left(P_{2 A}\right) ; n_{H^{1}} \frac{@ A}{@_{2} P_{2 A}}<0
$$

Proposition 1

(i) An increase in the economy's capital labor ratio $n_{H}$ will reduce the second period price of the high-tech good:

$$
\frac{\varrho_{2 \mathrm{~A}}}{\mathrm{Q}_{\mathrm{H}}}=\frac{1}{\mathrm{~J}} 1+1 \mathbf{h}^{\mathrm{i}}<0
$$

(ii) An increase in the productivity parameter ${ }^{1}$ will reduce the second period price $\mathrm{P}_{2 \mathrm{~A}}$ :

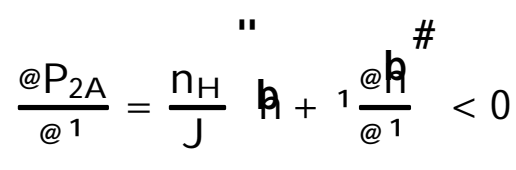


(iii) An increase in the bargaining power of the ..rm, ${ }^{-}$, will increase the second period price $\mathrm{P}_{2 \mathrm{~A}}$ :

$$
\frac{\varrho_{2 \mathrm{~A}}}{@^{-}}=\frac{1}{\mathrm{~J}} \frac{\mathrm{@A}^{\#}}{\varrho^{-}}>0
$$

(iv) An increase in the education cost parameter $®$ will increase the second period price $\mathrm{P}_{2 \mathrm{~A}}$ :

$$
\frac{@_{2 A}}{@ B}=\frac{{ }^{1} n_{H}}{J} \frac{\Phi_{A}}{@ R}>0
$$

R emark: Result (i) is obvious because a higher $n_{H}$ increases supply relative to demand, at any given price. Result (ii) is also plausible, because a higher ${ }^{1}$ will increase human capital accumulation at any given $\mathrm{P}_{2}$, resulting in a greater supply of good $\mathrm{H}$ in period 2 at any given $\mathrm{P}_{2}$ (i.e., a rightward shift in the supply curve), and hence the equilibrium price must fall in autarky. As to (iii), a greater bargaining power of the ..rm means that, from the worker's point of view, investment in human capital becomes less attractive, and hence the investment level will be reduced, thus causing second period output to fall, and price to rise.

The exects of changes in the parameters ${ }^{1} ;{ }^{-} ;{ }^{\circledR}$, and $n_{H}$ on second period wage can be computed from (7). For example,

$$
\begin{gathered}
\frac{@ N_{2 A}}{@ M_{H}}=\frac{@ N_{2 A}}{@ P_{2 A}} \frac{@ P_{2 A}}{@ m_{A}}>0 \\
\frac{@ N_{2 A}}{@}=\frac{@ N_{2 A}}{@} j_{P_{2 A}} \text { const }+\frac{@ N_{2 A}}{@ P_{2 A}} \frac{@ P_{2 A}}{@}
\end{gathered}
$$

which is ambiguous in sign. Similarly, $\frac{a N_{2 A}}{(A)}$ is also ambiguous in sign.

\subsection{Loss from trade}

We model the passage from autarky to free trade as follows. In period 1 , before labor allocation decisions are made, the government announces that the country will be opened to trade in period 2 . Thus, everyone expects the price of the high-tech good will be the world price, $\mathrm{P}_{2 T}$, not the aut arkic price $P_{2 A}$. We now show that a developing country (a country that would become 
an importer of the high-tech good when trade is opened in period 2) will suxer a welfare loss, in the sense that the life-time utility of a representative consumer is lower under the free trade regime (meaning no-trade in period 1 , and free trade in period 2) than under complete autarky.

Consider an open economy that imports the high-tech good under free trade in period 2. For this economy, the move from autarky to free trade may be represented by a decrease in $P_{2}$ (relative to its autarkic $P_{A 2}$ ). Note that $P_{1}$ remains unchanged, as it is determined by equation (16) alone. What is the exect of this decrease in $\mathrm{P}_{2}$ on the welfare of the representative consumer? Intuitively, the announcement in period 1 that trade will be opened in period 2 causes workers to invest less in education. Their life time wage income (net of exort cost), $M$, however, remains at $W_{G}(1+\#$ :T heir dividend income will be axected by the fall in $P_{2}$. Formally, the exect of a fall in $P_{2}$ on the welfare is computed as follows.

Recall the demand functions

$$
X_{H 1}^{i}\left(P_{1}\right)=D\left(P_{1}\right), X i_{H 2}^{i}\left(P_{2}\right)=D\left(P_{2}\right)
$$

where $D(:)$ is the inverse function of $u^{q}(:)$. The demand for the numeraire good $\mathrm{G}$ can then be inferred from the budget constraint. Thus

$$
X_{1 G}^{i}+ \pm X X_{1 G}^{i}=M+n_{H i} i \quad P_{1} D\left(P_{1}\right) i \quad \pm P_{2} D\left(P_{2}\right)
$$

Substituting (22) and (23) into the direct utility function, we obtain the life-time indirect utility function

$$
\begin{gathered}
V\left(P_{1} ; P_{2} ; M+n_{H i}\right)=u\left(D\left(P_{1}\right)\right)+ \pm u\left(D\left(P_{2}\right)\right)+n_{H} i \\
+M ; P_{1} D\left(P_{1}\right) i \pm P_{2} D\left(P_{2}\right)
\end{gathered}
$$

The exect of an increase in $\mathrm{P}_{2}$ on the welfare of the representative consumer is

$$
\begin{gathered}
\left.\frac{d V}{d P_{2}}= \pm{ }^{9} 9\left(P_{2}\right) i \pm\left[P_{2} D 9 P_{2}\right)+D\left(P_{2}\right)\right]+n_{H} \frac{d_{1}}{d P_{2}} \\
=i \pm D\left(P_{2}\right)+n_{H} \frac{d_{1}}{d P_{2}}
\end{gathered}
$$


Now, from (12)

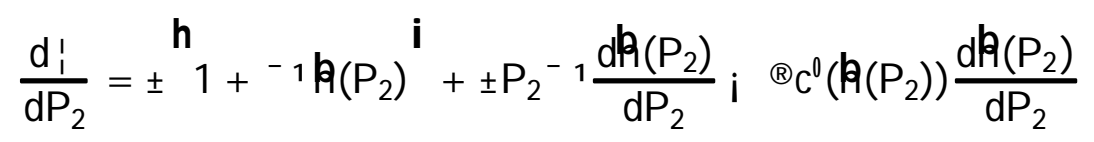

hence, recalling (4),

$$
\frac{d_{1}}{d P_{2}}= \pm 1+{ }^{1} g_{\left(P_{2}\right)} \quad i
$$

It follows that

$$
\frac{d V}{d P_{2}}=i \pm\left(P_{2}\right)+n_{H} \pm 1+{ }^{1} h\left(P_{2}\right)+n_{H} \pm^{-1} P_{2} \frac{d A\left(P_{2}\right)}{d P_{2}}
$$

Evaluating the right-hand side of (25) at the initial autarkic price $P_{2 A}$, we have, using (17),

$$
\frac{d V}{d P_{2}}=n_{H} \pm^{-1} P_{2} \frac{d A\left(P_{2}\right)}{d P_{2}}>0
$$

It follows that when a developing economy is opened to trade (the world price $P_{2}$ is bel ow $P_{2 A}$ ); there is a welfare loss. As clear from (26), this loss is caused by the fall in the level of investment in human capital. We state this result as Proposition 2:

Proposition 2: If the world price of the high-tech good $\mathrm{P}_{2}$ is marginally below a country's autarkic price $P_{2 A}$, the opening of trade will result in a welfare loss for that country.

Discussion: Proposition 2 is in sharp contrast with the standard gainsfrom-trade theorems. The confict can be explained easily. The standard gains-from-trade results rely on the assumption of perfect competition in the goods markets and the factor markets. In our model, the labor market is not perfectly competitive in period 2. Because of ..rm-speci..c human capital, each pair of worker-..rm is involved in a bargaining process in period 2 .

\section{Direction of Trade and Wage Gaps}

In this section, we turn to the exects of trade liberalization on the wage gap. We assume that the economy under consideration is under autarky in period 
1. We consider two scenarios. Under scenario 1, the economy remains under autarky in period 2, and everyone knows this in period 1. Under scenario 2, the economy will be open to free trade in period 2, and this is also known in period 1. We call the ..rst scenario the autarky scenario, and the second one the free trade scenario. We assume that the country produces both goods in each period, under either scenario. ( $T$ his is the incomplete specialization assumption.)

We consider a two-country world in which countries dixer in endowments $\left(n_{H}\right)$, technology $\left({ }^{1}\right)$, and the cost of education $(\circledR) .{ }^{9}$ If the two countries dixer only in the parameter $n_{H}$, then the country with a greater $n_{H}$ will have a lower autarkic price $P_{2 A}$. This country will therefore export the high-tech good under free trade. This is an endowment-based explanation of trade ${ }^{10}$.

If the two countries have identical $n_{H}$, then, ceteris paribus, the country with a higher ${ }^{1}$ will have a lower autarkic price $\mathrm{P}_{2 \mathrm{~A}}$, and therefore will export thehigh-tech good under free trade. This is a technology-based explanation of trade. Similarly, dixerence in ${ }^{\circledR}$ provides an education-cost-based explanation of trade.

M ore generally, for any given country, if its second period autarkic price $P_{2 A}$ of the high-tech good is smaller [respectively, greater] than the free trade world price $\mathrm{P}_{2 \mathrm{~T}}$ of that good, then the opening of trade in period 2 (fully anticipated in period 1) will make that country an exporter [respectively, importer] of the high-tech good in period 2. Let us denote variables of a country by a superscript e $(\mathrm{m})$ if it exports (imports) the high-tech good after the opening of trade. We next determine the exects of free trade on wage gaps.

Let $W_{2 T}^{e}\left[\right.$ respectively, $W_{2 T}^{m}$ ] be the second period wage of a worker in the high-tech sector of a country that exports [respectively, imports] the hightech good under the free trade scenario. Let $W_{2 A}^{e}$ [respectively, $W_{2 A}^{m}$ ] be the second period wage of a worker in the high-tech sector of the same country under the autarky scenario.

We begin by considering within-country wage gaps. We call $W_{2 T}^{e}-W_{G}$ the wage gap (between skilled workers and unskilled ones) under free trade, of a high-tech exporting economy. We want to compare this gap to the corresponding wage gap under autarky, $W_{2 A}^{e} i W_{G}$. Similarly, $W_{2 T}^{m}-W_{G}$ is called the wage gap under free trade, of a high-tech importing economy. We

\footnotetext{
${ }^{9}$ Dixerences in $\circledast$ rełect cross-country dixerences in education cost.

${ }^{10} \mathrm{~T}$ his is somewhat similar to the $\mathrm{F}$ indlay-K ierzkowski result.
} 
want to compare this gap to the corresponding wage gap under autarky, $W_{2 A}^{m}$ i $W_{G}$.

Proposition 3: (Exect of trade on wage gaps) For each worker in the high-tech sector, free trade

(i) increases the wage gap in the high-tech exporting country (relative to its wage gap under autarky)

(ii) reduces the wage gap of the high-tech importing country (relative to its wage gap under autarky)

Proof: For (i), we must show that $W_{2 \pi}^{e}-W_{G}$ exceeds $W_{2 A}^{e} i W_{G}$. For an exporting country, $\mathrm{P}_{2 T}^{e}, \mathrm{P}_{2 \mathrm{~A}}^{e}$. Therefore, using (7),

$$
W_{2 T}^{e}, W_{2 A}^{e}
$$

For (ii), note that for an importing country, $\mathrm{P}_{2 A}^{m}, \mathrm{P}_{2 \mathrm{~T}}^{m}$. Therefore

$$
W_{2 A}^{m} i W_{G}, W_{2 T}^{m} i W_{G}
$$

A similar argument applies to the importing country.

R emark: Proposition 3 shows that the exect of international trade on the wage gap between skilled and unskilled workers depends on the pattern of trade. Countries that export the high-tech good will see the wage gap increase, but importing countries will actually ...nd that the wage gap decreases with the opening of trade. The intuition for these results is clear. For example, in the country that exports the high-tech good, the opening of trade will increase the price of the high-tech good. This increases pro..ts in that industry and, since skilled workers bargain with ..rms over wages, the workers will share in those increased pro..ts through the bargaining process. We can also use these results to say something about inter-country wage gaps.

Corollary: The dixerence between the wage of skilled workers in the exporting economy and the importing economy under free trade, $W_{2 T}^{e} i W_{2 T}^{m}$, exceeds the autarkic dixerence, $W_{2 A}^{e} i W_{2 A}^{m}$.

Proof: From (28),

$$
i W_{21}^{m}, i W_{2 A}^{m}
$$

Adding (27) to (29),

$$
W_{2 T}^{e} \text { i } W_{2 T}^{m}, W_{2 A}^{e} \text { i } W_{2 A}^{m}
$$


R emark: The corollary indicates that trade will also increase the wage gap between skilled workers across countries. Workers in the high-tech sector in the exporting country will see their wage rise relative to their counterparts in countries that import the high-tech good. This is a direct consequence of the fact that skill premia are increasing in the exporting country, but decreasing in the importing country.

When trade is endowment-base, equation (30) has a special interpretation as explained in the next proposition.

Proposition 4: (Wage equalization) If trade is endowment-based, second-period wages for skilled workers are equalized across countries under free trade, given the incomplete specialization assumption. The country that exports the high-tech good under free trade has low autarkic wages of skilled workers.

Proof: From (7), $W_{2 T}^{e}=W_{2 T}^{m}$ if countries dixer only in $n_{H}$. With endowment-based trade, the left-hand side of (30) is zero, implying $W_{2 A}$ $W_{2 \mathrm{~A}}^{\mathrm{m}}$.

R emark: On the other hand, if trade is technology-based, driven by, for example, the dixerence in ${ }^{1},\left({ }^{1} \mathrm{e}>1 \mathrm{~m}\right)$, then, as is clear from (7),

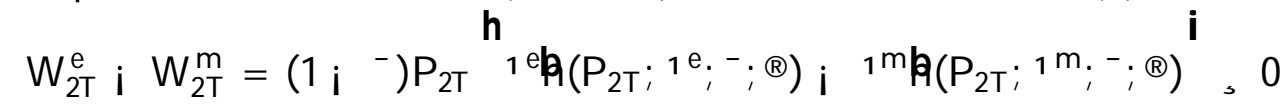

that is, under free trade, the wage of skilled workers in the exporting country is higher than in the importing country. Then the left-hand side of (30) is positive, and the right-hand side may be positive or negative.

We next turn to consideration of how trade axects the decisions of workers about how much human capital to accumulate.

Proposition 5: (Exect of trade on human capital accumulation) The opening of trade increases the accumulation of human capital in the country whose autarkic price $\mathrm{P}_{2 \mathrm{~A}}$ is lower than the free-trade price $\mathrm{P}_{2 T}$, and decreases the accumulation of human capital in the country whose autarkic price $P_{2 A}$ is higher than the freetrade price $P_{2 T}$.

Proof: From (6), and $P_{2 A}^{e}<P_{2 T}$

$$
h_{\AA}^{e}<h_{\top}^{e}
$$

Similarly, $h_{A}^{m}>h_{T}^{m}$.

R emark: In addition to price exects, trade also has an in $¥$ uence on human capital accumulation. Proposition 5 shows that trade enhances human 
capital accumulation in countries that export the high tech good and reduces human capital accumulation in the importing country. This result is important because it implies that, to some extent, trade-induced wage gaps are the result not only of direct price exects on wages, but also due to the exect trade has on the incentive to accumulate human capital.

We next show that in the country that exports the high-tech good, favorable trade and technology changes tend to increase the wage gap. De.ne the wage gap for a high-tech exporting country for a given trade volume and level of technology to be $\phi=W_{2} ; W_{G}$. Let us introduce two disturbances for this economy: it experiences a rise in ${ }^{1}$ (improved technology) and it confronts a $\neq$ ood of excess supply of good $G$ from a collection of developing economies, which causes the relative price of good $\mathrm{G}$ to fall (i.e., the price $\mathrm{P}_{2}$ rises, a favorable terms of trade shock.) Then the change in this economy's wage gap can be decomposed into two exects, namely the technology exect and the trade exect:

$$
d\left(W_{2} ; W_{G}\right)=\frac{@\left(W_{2} ; W_{G}\right)}{@} d^{1}+\frac{@\left(W_{2} ; W_{G}\right)}{@ P_{2}} d P_{2}
$$

where, from (2) and (6), the technology exect is

$$
\frac{@\left(W_{2} ; W_{G}\right)}{@} j_{P_{2}=\text { const }}=(1 ;-) P_{2} A+{ }^{1} \frac{@ A}{@} j_{P_{2}=\text { const }}>0
$$

and the trade exect is

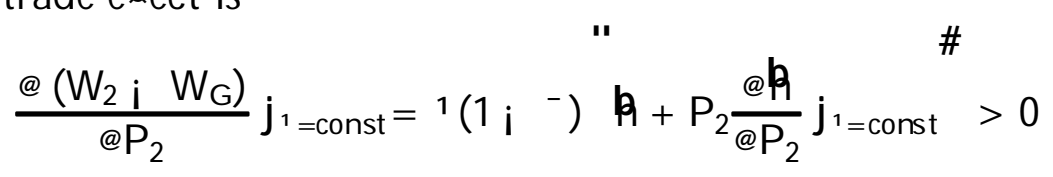

Taken together equations (32) and (33) imply that favorable technology and trade shocks tend to increase the wage gap in the high-tech exporting country, while unfavorable shocks will reduce the wage gap. These results are summarized in proposition 6.

Proposition 6: In the country that exports the high-tech good, favorable (unfavorable) technology and trade shocks increase (decrease) the wage gap between skilled and unskilled workers.

Discussion: The combination of very favorable technology shocks and trade shocks (favorable or unfavorable) may explain the stylized fact that 
wage gaps have been increasing in all countries. While our focus is on the theoretical decomposition, it seems appropriate to quote Deardora (2000,p. 478): "T he outcome of that debate, it seems, is a near consensus that trade has indeed been a signi..cant cause of these lab or market changes, but also that it has been less important quantitatively than other causes, and most likely less important than technology."

\section{Extensions}

\subsection{Income Distribution}

In this subsection we analyze the exect of trade and capital accumulation on factor incomes. Recall that workers within a given country are ex ante identical. Thus no matter which industry they choose to work in, their life-time income (net of exort cost), in terms of good $G$, is $W_{G}\left(1+\frac{1}{1+r}\right)$. By assumption of an interior solution, they consume both goods. In this section, we modify our assumption: now workers are not shareholders. Then, when a country changes its trading status from autarky to exporter of the high-tech good, the domestic price $\mathrm{P}_{2}$ rises, and workers are worse ox. They would therefore prefer autarky to free trade. Capitalist's pro..t is increasing in $P_{2}$. Thus, capitalists in the high-tech sect or prefer exporting to autarky. For a country that would become an importer of the high-tech good under free trade, capitalists in the high-tech sector would prefer autarky to free trade, while the workers would prefer trade to autarky.

\subsection{Externalities}

We have assumed that the accumulation of human capital by a worker does not have direct spillover exects on other workers. In the endogenous growth literature, however, many authors argue that there exists signi..cant spillovers. Let us indicate brieły how our model can be modi..ed to take into account such bene..cial externalities. An intuitively appealing formulation would be to modify our model by specifying that the parameter ${ }^{1}{ }_{i}$ for individual $i$ is an increasing function of the average amount $h$ of accumulation of human capital in the industry and of $\mathrm{N}_{\mathrm{H}}$

$$
{ }^{1}{ }_{i}={ }^{10}+\hat{A}\left(\hat{h} N_{H}\right) ; \quad A^{0}>0
$$


The positive externality displayed in (34) implies that a laissez-faire regime would result in an inec ciently low level of accumulation of human capital. Since one person's investment in his human capital has a positive spillover exect on the human capital of others, the government of a small economy might want to pursue policies that increase the price of the hightech good. This would mean that the country that imports the high tech good under free trade may have an incentive to prohibit such imports so as to raise the domestic price $\mathrm{P}_{2}$, thus encouraging more human capital accumulation (as there is under-investment in human capital under laissez-faire). Of course, there would presumably be other policies that would be more et cient ways to deal with such externalities, but political or revenue considerations could lead to the adoption of protection.

\subsection{Education Policy}

In this subsection we brieły indicate how one might want to analyze education policy in the context of our model. One could think of education policy axecting two variables in our model, the cost of acquiring education, ${ }^{\circledR}$ or the productivity of education ${ }^{1}$. Think of education policy as axecting ${ }^{1}$. Let ${ }^{10}$ denote the initial level of the variable ${ }^{1}$. What is the marginal social bene.t of a policy that directly gives rise to an increase in ${ }^{10}$ ? Under free trade, for a small open economy, $\mathrm{P}_{2}$ is exogenous and hence any increase in ${ }^{10}$ to a higher value, say ${ }^{10}+"$; will increase $h$, i.e. increase human capital accumulation. Under autarky, things are slightly dixerent: any increase from ${ }^{10}$ to ${ }^{10}+$ " will cause the autarkic equilibrium price $P_{2 A}$ to fall to some level $P_{2 A}<P_{2 A}^{0}$, and this may discourage human capital accumulation. Since the demand curve for good $\mathrm{H}$ is negatively sloped, this price fall means that the new equilibrium quantity consumed is greater than the old equilibrium quantity consumed. This in turns means that the new exective supply $\left({ }^{10}+"\right) h\left({ }^{10}+" ; P_{2 A}\right)$ exceeds the old ${ }^{10} h\left({ }^{10} ; P_{2 A}\right)$, but we cannot be certain whether $\mathrm{h}\left({ }^{10}+" \mathbb{P}_{2 A}\right)$ exceeds $h\left({ }^{10} ; P_{2 A}\right)$. Therefore, under autarky, a policy that directly increases ${ }^{1}$ may indirectly reduce $h$. If there are spillover exects in the economy, and if these exects depend on $h$ rather than ${ }^{1} h$, then under autarky, a policy that increases ${ }^{1}$ could be harmful. To summarize, education policy that makes human capital more productive al ways improves welfare in a free trading economy. In an autarkic economy such an education policy may actually reduce welfare. 


\subsection{Uncertainty}

Wecan introduce uncertainty about second period price, but the basic results go through. Let $s_{1}$ be the amount of savings for a worker in period 1 . At the beginning of period 2 , when the uncertainty about period 2 price has been resolved, the worker knows that his second period wage is $\mathrm{W}_{\mathrm{G}}+\left(1 \mathrm{i}^{-}\right)^{1} \mathrm{hP} \mathrm{P}_{2}$ and therefore his second period utility is

$$
\begin{aligned}
& \mathrm{I}_{2}\left[\mathrm{P}_{2} ; \mathrm{h} ; \mathrm{s}_{1}\right]=\max _{\mathrm{X}_{2 \mathrm{H}}} \mathrm{u}\left(\mathrm{X}_{2 \mathrm{H}}\right)+\left[\mathrm{s}_{1}(1+\mathrm{r})+\mathrm{W}_{\mathrm{G}}+\left(\mathrm{I}_{\mathrm{i}^{-}}\right)^{1} \mathrm{hP}_{2} \mathrm{i} \mathrm{P}_{2} \mathrm{X}_{2 \mathrm{H}}\right] \\
& =u\left[D\left(P_{2}\right)\right] i P_{2} D\left(P_{2}\right)+s_{1}(1+r)+W_{G}+\left(1 i^{-}\right)^{1} h P_{2}
\end{aligned}
$$

with

$$
\begin{aligned}
& \frac{\mathfrak{G}_{2}}{\mathrm{GP}_{2}}=\mathrm{i} D\left(\mathrm{P}_{2}\right)+\left(1 \mathrm{i}^{-}\right)^{1} \mathrm{~h} \\
& \left.\frac{\varrho^{2} I_{2}}{\left(\mathrm{P}_{2}^{2}\right.}=\text {; } D 9 P_{2}\right)>0 \\
& \frac{\oint_{2}}{\text { @h }}=\left(1 i^{-}\right)^{1} P_{2}>0 \\
& \frac{@_{2}}{@_{1}}=1+r
\end{aligned}
$$

In the ..rst period, before the uncertainty is resolved, the worker chooses $\mathrm{h}$ and to maximize his expected two-period utility

$$
E U=u\left(D_{1}\left(P_{1}\right)\right) \text { i }\left[W_{1} \text { i } \mathbb{B C}(h) \text { i } s_{1} \text { i } P_{1} D_{1}\left(P_{1}\right)\right]+\# I_{2}\left[P_{2} ; h ; s_{1}\right]
$$

where $E$ is the expectation operator (and the random variable is $P_{2}$ ).

It is clear from the above that in this simple formulation, uncertainty does not axect the decision on human capital investment. 


\section{Concluding Remarks}

We have developed a model of ..rm-speci..c human capital accumulation and explored some of its implications. We showed that the opening of trade can reduce the welfare of a country which would import the high-tech good under free trade. Concerning the exect of trade on the wage gap between high and low skill workers, we showed that trade liberalization increases the wage gap in the country that exports the high-tech good, and decreases the wage gap in the other country. In the real world, countries may face simultaneously a trade shock and a technology shock. Proposition 6 provides a way of decomposing the changes in wage gaps.

Other issues that can be considered within the framework of our model include (i) wage dispersion (this is particularly important if individuals differ in their ability to learn),(ii) political economy e.g., lobbying activities by potential gainers and losers, (iii) migration e.g., since it is cheaper to accumulate high-tech human capital in advanced countries, there is an incentive to migrate to these countries. Some results concerning wage dispersion have been reported in Long, Riezman, and Soubeyran (2001) in a model where workers dixer with respect to learning ability.

\section{R eferences}

Becker, Gary, 1962, Investment in Human Capital: A Theoretical A nalysis, J ournal of Political E conomy:70, 9-49.

B orjas, George J . and Valerie A. Ramey, 1995, Foreign Competition, Market Power, and Wage Inequality, Quarterly J ournal of E conomics, November 1995, 1075-1110

Brander, J. A. and M. S.Taylor, 1998, Open Access Renewable Resources: Trade and Trade Policy in a Two-country Model, J ournal of International E conomics 44, 181-209.

Carmicheal, H. L., 1989, Self-enforcing Contracts, Shirking, and LifeCycle Exects, J ournal of E conomic Perspectives 3, 65-84.

Chichilniski, G ., 1994,N orth-South Trade and the Global E nvironment, A merican Economic Review 84(4), 851-73. 
Davis, D., 1998, Does European Unemployment Prop up A merican Wage?, A merican Economic Review 88(3), 478-494, J une 1998.

Dinopoulos, E. and P. Segerstrom, 1999, A Shumpeterian Model of Protection and R elative Wages, American Economic Review, Vol 89(3), 450-472.

Deardorx, A lan, 2000, P olicy I mplications of Trade and Wage Debates, Review of International Economics 8 (3), 478-96.

Falvey, Rodney, 1999, Trade Liberalization and Factor Price Convergence, J ournal of International Economics, 49(1), 195-210.

Findlay, R. and H. Kierzkowski, 1983, "Int ernational Trade and Human Capital: A Simple General Equilibrium Model," J ournal of Political Economy, Vol. 91 (6) pp. 957-78.

Freeman, R. B., 1995, A re Your Wages Set in Beijing? J ournal of Economics Perspectives, 9(3), 15-32, Summer 1995.

Hirschman, Albert O., 1969, "How to divest in Latin America, and Why," Essay in International Finance No 76, International F inance Section, Princeton University, November 1969.

Hutchens, R., 1989, Seniority, Wages, and Productivity: A turbulent Decade, J ournal of E conomic Perspectives 3, 49-64.

Kemp, M urray C, 1962, "The Gains from International Trade," Economic J ournal 72, 303-319

Kemp, M urray C, 1995, The Gains from Trade and the Gains from A id, R outhledge, N.Y .

Krugman, Paul, 1995, Growing World Trade: Causes and Consequences, B rookings Papers on E conomic Activity, 1, 251-270.

K rugman, Paul, 2000, Technology, Trade, and Factor Prices, J ournal of International E conomics 50, 51-72.

Leamer, E.E., 1998, In Search of Stolper-Samuel son Linkages between International Trade and Lower Wage Rates, in S. Collins ( ed.) Imports, Exports, and the A merican Worker, Washington, D.C., Brookings Institution, 141-202. 
Leamer, E.E., 2000, What's the Use of Factor Contents? J ournal of International E conomics 50, 17-50.

Long, N go Van and Kar-yiu Wong, 1997, Endogenous Growth and International Trade: A Survey, Chapter 1 in B. J ensen and K ar-yiu Wong, Dynamics, Economic G rowth, and International Trade, University of Michigan P ress, Ann A rbor, Michigan.

Long, Ngo Van, Raymond Riezman, and Antoine Soubeyran, 2001, Trade, Wage Gaps, and Speci..c Human Capital Accumulation, CIRANO working paper 2001s-36, Cirano, Montreal (http:// cirano.qc.ca).

Lucas, Robert E., 1988, On the Mechanics of E conomic Development, J ournal of M onetary E conomics 22, 3-42.

N eary, P.J ., 2000, Competition, Trade and Wages, Typescript, University College Dublin.

St okey, Nancy L., 1991, Human Capital, Product Quality, and Growth, Quarterly J ournal of Economics 106, 587-616.

Tyers, Rod, and Yongzhen Yang, 1999, European Unemployment , US Wages, and the A sian E mergence, Working Paper \# 367, Faculty of Economics and Commerce, A ustralian National University.

Wood, A drian, 1994, N orth-South Trade, Employment, and I nequality: Changing Fortunes in a Skill-driven World, Clarendon P ress, Oxford.

Young, Alwyn, 1991, Learning-by-doing and the Dynamics of International Trade, Quarterly J ournal of Economics 106, 369-405 


\title{
CESifo Working Paper Series
}

\author{
(for full list see www.cesifo.de)
}

844 Peter Fredriksson and Per Johansson, Program Evaluation and Random Program Starts, January 2003

845 Bernd Hayo and Matthias Wrede, Fiscal Equalisation: Principles and an Application to the European Union, January 2003

846 Syed M. Ahsan and Jaideep Oberoi, Inequality, Well-being and Institutions in Latin America and the Caribbean, January 2003

847 Chang Woon Nam and Doina Maria Radulescu, The Role of Tax Depreciation for Investment Decisions: A Comparison of European Transition Countries, January 2003

848 V. Bhaskar and Steinar Holden, Wage Differentiation via Subsidised General Training, January 2003

849 Paloma Lopez-Garcia, Labour Market Performance and Start-up Costs: OECD Evidence, January 2003

850 Christian Keuschnigg and Soren Bo Nielsen, Public Policy for Start-up Entrepreneurship with Venture Capital and Bank Finance, January 2003

851 Yin-Wong Cheung, Menzie D. Chinn, and Eiji Fujii, China, Hong Kong, and Taiwan: A Quantitative Assessment of Real and Financial Integration, January 2003

852 Gregory D. Hess, The Economic Welfare Cost of Conflict: An Empirical Assessment, February 2003

853 Douglas J. Cumming and Jeffrey G. MacIntosh, Comparative Venture Capital Governance. Private versus Labour Sponsored Venture Capital Funds, February 2003

854 Eckhard Janeba and John Douglas Wilson, Decentralization and International Tax Competition, February 2003

855 Tapio Palokangas, Capital Accumulation and Employment Cycles in a Model of Creative Destruction, February 2003

856 Brendan Walsh, When Unemployment Disappears: Ireland in the 1990s, February 2003

857 Luis H. R. Alvarez and Erkki Koskela, A General Approach to the Stochastic Rotation Problem with Amenity Valuation, February 2003

858 Christian Schultz, Strategic Campaigns and Redistributive Politics, February 2003 
859 Ernst Fehr and Joseph Henrich, Is Strong Reciprocity a Maladaptation? On the Evolutionary Foundations of Human Altruism, February 2003

860 Haizhou Huang, Dalia Marin, and Chenggang Xu, Financial Crisis, Economic Recovery and Banking Development in Former Soviet Union Economies, February 2003

861 Pedro Cardoso and Bernard M.S. van Praag, How Sustainable Are Old-age Pensions in a Shrinking Population with Endogenous Labour Supply?, February 2003

862 Volker Meier, Efficient Transfer of Aging Provisions in Private Health Insurance, February 2003

863 Edward Castronova, Theory of the Avatar, February 2003

864 Robert S. Chirinko, Hans van Ees, Harry Garretsen, and Elmer Sterken, Investor Protections and Concentrated Ownership: Assessing Corporate Control Mechanisms in the Netherlands, February 2003

865 Bernard M.S. van Praag and Pedro Cardoso, The Mix Between Pay-as-you-go and Funded Pensions and what Demography has to do with it, February 2003

866 Ernst Fehr, Urs Fischbacher, Bernhard von Rosenbladt, Jürgen Schupp, and Gert G. Wagner, A Nation-Wide Laboratory. Examining Trust and Trustworthiness by Integrating Behavioral Experiments into Representative Survey, February 2003

867 Frank Heinemann, The Inflationary Impact of Wage Indexation, February 2003

868 Eytan Sheshinski, Bounded Rationality and Socially Optimal Limits on Choice in a Self-Selection Model, February 2003

869 M. Hashem Pesaran, Estimation and Inference in Large Heterogenous Panels with Cross Section Dependence, February 2003

870 Luis H. R. Alvarez and Erkki Koskela, On the Tree-Cutting Problem under Interest Rate and Forest Value Uncertainty, February 2003

871 Norbert Berthold and Rainer Fehn, Unemployment in Germany: Reasons and Remedies, February 2003

872 Clemens Fuest, Bernd Huber, and Philipp Tilleßen, Tax Policy and Entrepreneurship in the Presence of Asymmetric Information in Capital Markets, February 2003

873 Eytan Sheshinski, Optimum and Risk-Class Pricing of Annuities, February 2003

874 Willi Leibfritz, Paul O'Brien and Jean-Christophe Dumont, Effects of Immigration on Labour Markets and Government Budgets - An Overview, February 2003

875 M. Hashem Pesaran and Allan Timmermann, How Costly is it to Ignore Breaks when Forecasting the Direction of a Time Series?, February 2003 
876 Thorvaldur Gylfason and Gylfi Zoega, Education, Social Equality and Economic Growth: A View of the Landscape, February 2003

877 Robin Boadway and Jean-François Tremblay, Public Economics and Startup Entrepreneurs, February 2003

878 Erkki Koskela and Roope Uusitalo, The Un-Intended Convergence: How the Finnish Unemployment Reached the European Level, February 2003

879 Robert Fenge and Volker Meier, Pensions and Fertility Incentives, February 2003

880 Eytan Sheshinski, Note on Income Taxation and Occupational Choice, February 2003

881 A B Atkinson, Income Inequality in OECD Countries: Data and Explanations, February 2003

882 Thomas Gehrig and Rune Stenbacka, Venture Cycles: Theory and Evidence, February 2003

883 Ralf Becker and Thomas Hellmann, The Genesis of Venture Capital - Lessons from the German Experience, March 2003

884 Eytan Sheshinski, Note on the Optimum Pricing of Annuities, March 2003

885 Paul De Grauwe and Magdalena Polan, Globalisation and Social Spending, March 2003

886 F. van der Ploeg, Do Social Policies Harm Employment and Growth?, March 2003

887 Mirjam van Praag, Initial Capital Constraints Hinder Entrepreneurial Venture Performance: An empirical analysis, March 2003

888 Bernard Steunenberg, Coordinating Sectoral Policymaking: Searching for Countervailing Mechanisms in the EU Legislative Process, March 2003

889 Eytan Sheshinski, Optimum Delayed Retirement Credit, March 2003

890 Frederick van der Ploeg, Rolling Back the Public Sector - Differential effects on employment, investment and growth, March 2003

891 Paul De Grauwe and Marc-Alexandre Sénégas, Monetary Policy in EMU when the Transmission is Asymmetric and Uncertain, March 2003

892 Steffen Huck and Kai A. Konrad, Strategic Trade Policy and the Home Bias in Firm Ownership Structure, March 2003

893 Harry Flam, Turkey and the EU: Politics and Economics of Accession, March 2003

894 Mathias Hoffmann and Ronald MacDonald, A Re-examination of the Link between Real Exchange Rates and Real Interest Rate Differentials, March 2003 
895 Badi H. Baltagi, Espen Bratberg, and Tor Helge Holmås, A Panel Data Study of Physicians' Labor Supply: The Case of Norway, March 2003

896 Dennis C. Mueller, Rights and Citizenship in the European Union, March 2003

897 Jeremy Edwards, Gains from Trade in Tax Revenue and the Efficiency Case for Trade Taxes, March 2003

898 Rainer Fehn and Thomas Fuchs, Capital Market Institutions and Venture Capital: Do They Affect Unemployment and Labour Demand?, March 2003

899 Ronald MacDonald and Cezary Wójcik, Catching Up: The Role of Demand, Supply and Regulated Price Effects on the Real Exchange Rates of Four Accession Countries, March 2003

900 R. Selten, M. Schreckenberg, T. Pitz, T. Chmura, and S. Kube, Experiments and Simulations on Day-to-Day Route Choice-Behaviour, April 2003

901 Stergios Skaperdas, Restraining the Genuine Homo Economicus: Why the Economy Cannot be Divorced from its Governance, April 2003

902 Yin-Wong Cheung, Menzie D. Chinn, and Antonio Garcia Pascual, What Do We Know about Recent Exchange Rate Models? In-Sample Fit and Out-of-Sample Performance Evaluated, April 2003

903 Mika Widgrén, Enlargements and the Principles of Designing EU - Decision-Making Procedures, April 2003

904 Phornchanok Cumperayot, Dusting off the Perception of Risk and Returns in FOREX Markets, April 2003

905 Kai A Konrad, Inverse Campaigning, April 2003

906 Lars P. Feld and Stefan Voigt, Economic Growth and Judicial Independence: Cross Country Evidence Using a New Set of Indicators, April 2003

907 Giuseppe Bertola and Pietro Garibaldi, The Structure and History of Italian Unemployment, April 2003

908 Robert A.J. Dur and Otto H. Swank, Producing and Manipulating Information, April 2003

909 Christian Gollier, Collective Risk-Taking Decisions with Heterogeneous Beliefs, April 2003

910 Alexander F Wagner, Mathias Dufour, and Friedrich Schneider, Satisfaction not Guaranteed - Institutions and Satisfaction with Democracy in Western Europe, April 2003

911 Ngo Van Long, Raymond Riezman, and Antoine Soubeyran, Trade, Wage Gaps, and Specific Human Capital Accumulation, April 2003 